\title{
Nomenclature of the Oceans
}

\section{Author(s): Rod. I. Murchison}

Source: The Geographical Journal, Vol. 1, No. 6 (Jun., 1893), pp. 535-536

Published by: geographicalj

Stable URL: http://www.jstor.org/stable/1773967

Accessed: 27-06-2016 06:43 UTC

\section{Your use of the JSTOR archive indicates your acceptance of the Terms \& Conditions of Use, available at}

http://about.jstor.org/terms

JSTOR is a not-for-profit service that helps scholars, researchers, and students discover, use, and build upon a wide range of content in a trusted digital archive. We use information technology and tools to increase productivity and facilitate new forms of scholarship. For more information about JSTOR, please contact support@jstor.org.

The Royal Geographical Society (with the Institute of British Geographers), Wiley are collaborating with JSTOR to digitize, preserve and extend access to The Geographical Journal 


\section{NOMENCLATURE OF THE OCEANS.}

IT is interesting in connection with the nomenclature of the greater divisions of the hydrosphere to remember that a Committee was appointed by the Royal Geographical Society in 1845 to deal with the whole matter. This Committee met once, and was adjourned on January 27 th, 1845 , but there is no record of a subsequent meeting. The sub-divisions of the oceans now generally adopted date from this meeting, and as very full minutes of the discussion have been preserved, but were never published, it is desirable to place them on record.

1845.

January 27 th.

\section{The Committee ap} consideration the divisions of the ocean and the respective limits of these divisions met this day at two o'clock, there being present, Mr. Murchison, President, in the chair, Sir G. Back, Captain Beaufort, Sir John Franklin, Mr. Greenough, and Captain Smyth; Mr. Arrowsmith being also present.

The President having opened the business of the meeting, Mr. Greenough observed that the present divisions of the ocean and the names they received were very arbitrary, and that a systematic arrangement was desirable. He despaired of changing the common parlance in these matters, but was of opinion that geography, like other sciences, should have its philosophical system, and that, as in the cases of the Linnæan and Jussieuan systems of botany, etc., so a geographical system, if found to be a good one, would be received by the scientific world, particularly if accepted and encouraged by those departments, such as the Admiralty, \&c., whose sanction would go so far in such matters, and that what in the beginning would be confined to the scientific would become familiar to the many to great advantage of the science itself and of general knowledge. With regard to the particular object of the meeting, and in conformity with his conviction that a partial change in the present divisions of the ocean would be attended with no good results, he had prepared, in order to submit to the consideration of the meeting, a totally new division of the ocean into zones.

The President was of opinion that no great changes of the kind contended for by Mr. Greenough, however good they might be, were likely to be received unless brought forward prominently at a meeting of the British Association.

Mr. Greenough instanced Linnæus, Cuvier, \&c., as individuals whose systems had been universally adopted.

Captain Beaufort thought that, though the precise limits of the several oceans were not accurately defined, they were sufficiently so for all practical purposes. He saw no objection, however, to defining them more precisely; but was decidedly opposed to new names, such as those proposed by Mr. Greenough. He thought the change uncalled for, and, even if admitted by ourselves, was not likely to be adopted by other nations.

Captain Smyth regretted the very vague signification of the term "South Sea," and was of opinion that without any appearance of innovation the following divisions might be settled, viz.-The Arctic Ocean and the Antarctic Ocean ; the North Atlantic and South Atlantic; the North Pacific and South Pacific; the North Indian and South Indian Oceans. He nevertheless concurred with Mr. Greenough in the desirableness of a systematic arrangement of the Ocean founded upon philosophical 
principles, and saw no reason why there should not exist at the same time a philosophical and a popular arrangement of the facts of physical geography.

Sir George Back thought it advisable to retain the existing names of the oceans, but opined for a determination of their respective limits. In this opinion Sir John Franklin concurred.

The Secretary read some notes he had made, showing that both the divisions of the oceans and their respective limits were differently determined by different authorities abroad and by ourselves.

Sir John Franklin, Mr. Arrowsmith, and other gentlemen present then explained their several views as to the limits of the several oceans as popularly known. Finally the general opinion entertained was that the present names of Arctic, Antarctic, Atlantic, Indian, and Pacific Oceans be retained; that the limits of the Arctic and Antarctic Oceans be respectively the Arctic and Antarctic Circles; that the limits of the Atlantic on the north and south be the Arctic and Antarctic Circles. That its western limit be the coast of America as far south as Cape Horn, and thence prolonged on the meridian of that cape till it meets the Antarctic Circle; that its eastern limit be the shores of Europe and A frica as far south as the Cape of Good Hope, and thence prolonged on the meridian of Cape L'Agulhas, till that meridian cuts the Antarctic Circle; that the Indian Ocean do extend from India and Persia on the north to the Antarctic Circle on the south; that its western limit be the shores of Arabia and Africa as far south as Cape L'Agulhas, and thence along the meridian of that Cape to its intersection with the Antarctic Circle; that its eastern limit be the west coast of the Birman empire and a part of the Malayan Peninsula, the west cciast of Sumatra, Java, Timor, and Australia, as far as the southernmost point of Van Dieman's Land, and thence continued along the meridian of that point to its intersection with the Antarctic Circle; that the Pacific do extend from the Arctic Circle on the north to the Antarctic Circle on the south; that its western limit be the east coasts of Asia and of the island of Sumatra, the northern shore of Java, Flores, and Timor, and the coasts of Australia from Melville Island round to the southern point of Van Dieman's Land, and along its meridian to the Antarctic Circle, and that its eastern limit be the west coasts of America and the meridian of Cape Horn as far as the Antarctic Circle. It was further agreed that the Atlantic and Pacific Oceans be sub-divided into three portions: a northern and southern and an intertropical, and that the Indian Ocean have but two divisionsan intertropical andl southern.

This arrangement being agreed upon, Mr. Greenough and Captain Smyth were requested to concert together on the subject of a scientific system of classification of the oceans, seas, gulfs, bays, \&c., to be subsequently submitted at their convenience to the consideration of the Society.

(Signed) Rod. I. Murchrson.

\section{THE PHYSICAL AND INDUSTRIAL GEOGRAPHY OF CALIFORNIA.*}

By Professor E. W. HILGARD of San Francisco.

THE great change which has taken place in the physical conditions of California since the days of Bret Harte and Mark Twain is apparent from the fact, that for some time the only method of goldmining possible in certain districts, viz., the

* Report of paper read at the Berlin Geographical Society, February 4th, 1893. 